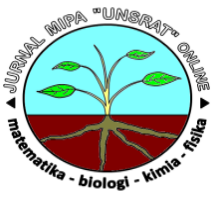

\title{
Aktivitas Penstabil Oksigen Singlet dari Hasil Fraksinasi Ekstrak Metanol Daun Kayu Manis (Cinnamomum burmanii) terhadap Fotooksidasi Asam Askorbat
}

\author{
Muhammad Fajrin A. Salima*, Johnly A. Roronga, Dewa G. Katjaa \\ aJurusan Kimia, FMIPA, Unsrat, Manado
}

K A T A K U N C I

Daun Kayu Manis

Fenolik

Penstabil Oksigen Singlet

Asam Askorbat

\begin{abstract}
A B S T R A K
Telah dilakukan penelitian tentang aktivitas penstabil oksigen singlet dari hasil fraksinasi ekstrak metanol daun kayu manis (Cinnamomum burmanii) terhadap fotooksidasi asam askorbat dengan menggunakan cahaya dan eritrosin sebagai sensitiser. Serbuk daun kayu manis diekstraksi secara maserasi dengan metanol 95 \% selama 3 x 24 jam, selanjutnya ekstrak yang diperoleh difraksinasi berturut-turut dengan pelarut n-heksan, etil asetat, butanol dan air. Penentuan kandungan total fenolik diukur dengan metode Folin-Ciocalteu dan aktivitas penstabil oksigen singlet diukur dengan laju penurunan konsentrasi asam askorbat. Hasilnya menunjukkan bahwa fraksi etil asetat memiliki kandungan total fenolik tertinggi yaitu 166,888 mg/g diikuti dengan fraksi butanol, n-heksan, dan air. Fraksi etil asetat juga memiliki aktivitas penstabil oksigen singlet yang kuat, ditunjukkan dengan laju kerusakan fotooksidatif asam askorbat yang kecil yaitu $-0,75 \mu g \cdot \mathrm{mL}^{-1} \cdot \mathrm{min}^{-1}$

A B S T R A C T

A study of singlet oxygen quenching activity has been done from the fractination result of methanol extract of cinnamon leaf (Cinnamomum burmanii) against photo-oxidation of ascorbic acid by using light and erythrosine as sensitized. The cinnamon leaf powder was extracted by macerating with 95\% methanol for $3 \times 24$ hours, then the extracts obtained was fractionated successively with n-hexane, ethyl acetate, butanol and water solvent. The determination of total phenolic content was measured by the Folin-Ciocalteu method and the singlet oxygen quenching activity was measured by the rate of decrease in ascorbic acid concentration. The results show that the ethyl acetate fraction has the highest total phenolic content of $166,888 \mathrm{mg} / \mathrm{g}$ followed by the fraction of butanol, n-hexane, and water, respectively. The ethyl acetate fraction also has a strong singlet oxygen quenching activity, indicated by a small photo-oxidative damage rate of ascorbic acid of $-0.75 \mu \mathrm{g} \cdot \mathrm{mL}^{-1} \cdot \mathrm{min}^{-1}$
\end{abstract}

K E Y W O R D S

Cinnamon Leaf

Phenolic

Singlet Oxygen Quenching

Ascorbic Acid

TERSEDIA ONLINE

1 Agustus 2017

\section{Pendahuluan}

Indonesia merupakan negara yang terkenal dengan kekayaan rempahnya. Rempah - rempah umumnya dimanfaatkan sebagai tanaman obat yang berkhasiat oleh tubuh. Salah satu khasiatnya yaitu sebagai antioksidan. Antioksidan merupakan substansi yang dapat menunda dan mencegah kerusakan oksidatif akibat adanya radikal bebas.
Radikal bebas merupakan derivat dari oksigen yang disebut sebagai spesies oksigen reaktif (SOR), termasuk di dalamnya adalah oksigen triplet $\left({ }^{3} \mathrm{O}_{2}\right)$, oksigen singlet $\left({ }^{1} \mathrm{O}_{2}\right)$, anion superoksida $\left(\mathrm{O}_{2}^{-}\right)$, radikal hidroksil $(\cdot \mathrm{OH})$, asam hipoklorit $(\mathrm{HOCl})$, dan hidrogen peroksida $\left(\mathrm{H}_{2} \mathrm{O}_{2}\right)$ (Araujo et al., 1998). Tidak seperti SOR lainnya, oksigen singlet adalah suatu spesies oksigen reaktif (SOR) yang non radikal elektrofilik (Min dan Boff, 2002). Oleh karena itu, oksigen singlet bisa mempengaruhi suatu proses

*Corresponding author: Jurusan Kimia FMIPA UNSRAT, Jl. Kampus Unsrat, Manado, Indonesia 95115; Email address: muhammadfajrin36@gmail.com Published by FMIPA UNSRAT (2017) 
oksidasi yang khas melalui penyerangan secara langsung senyawa yang kaya elektron tanpa keterlibatan radikal bebas. Oksidasi komponen biologi yang terinduksi oleh oksigen singlet berkaitan dengan berbagai peristiwa patologis seperti pigmentasi, katarak, penuaan kulit, dan kanker (Meucci et al. 1991). Hal ini disebabkan reaktivitasnya yang tinggi terhadap molekul biologi seperti protein, lipida, vitamin dan DNA yang sangat peka terhadap fotooksidasi terutama bila fotosensitiser seperti klorofil dan riboflavin terdapat dalam sistem tersebut (King dan Min, 2002; Choe dan Min, 2006).

Kayu manis merupakan salah satu jenis tanaman rempah yang terdapat di daerah sulawesi utara dan banyak dimanfaatkan oleh masyarakat luas sebagai penyedap makanan, bahan pewangi, dan berbagai bahan olahan kue. Kayu manis memiliki hasil utamanya yaitu kulit batang dan dahan, sedangkan hasil sampingnya yaitu ranting dan daun. Oleh karena itu, kayu manis dapat dijadikan sebagai hasil olahan seperti minyak atsiri dan oleoresin yang banyak digunakan dalam industri-industri farmasi, kosmetik, makanan, minuman, dan rokok (Heyne, 1987). Selain itu, tanaman kayu manis dikenal sebagai tanaman obat yang berkhasiat oleh tubuh dan mengandung sejumlah senyawa antioksidan yang dapat secara efektif sebagai penangkal spesies oksigen reaktif (Jakhetia et al., 2010).

Kayu manis merupakan jenis rempah dengan kandungan antioksidan paling tinggi dari rempah pasar dan rempah pabrik dibandingkan dengan rempah-rempah lainnya yaitu lada hitam, lada putih, jinten, ketumbar, dan biji pala (Nely, 2007). Sufriadi (2006) melaporkan daun kayu manis dapat menstabilkan khasiat antioksidasi ekstrak air buah mahkota dewa yaitu dengan menghambat tumbuhnya bakteri.

Aktivitas antioksidan berkaitan erat dengan senyawa fenolik pada tumbuhan. Efek antioksidan fenolik terutama disebabkan sifat-sifat reaksi reduksi-oksidasi dan merupakan hasil berbagai kemungkinan mekanisme seperti aktivitas penangkalan (scavenging) radikal bebas, aktivitas pengkelat (chelating) logam transisi dan aktivitas penstabilan (quenching) oksigen singlet (Silva et al., 2000). Senyawa fenolik dapat mencegah terjadinya reaksi fotooksidasi. Reaksi fotooksidasi mampu menginisiasi kerusakan oksidatif dengan kecepatan 1.500 kali lebih cepat dibanding kerusakan autooksidatif (Pokorny et al., 2001). Oleh karena itu, reaksi fotooksidasi dapat dihambat oleh penstabilan oksigen singlet.

Dalam penelitian Chua et al. (2008) menyatakan ekstrak dan fraksi ranting kayu manis memiliki potensi sebagai antioksidan. Ekstrak etanol dilakukan dengan fraksinasi pelarut $n$-heksan, etil asetat, butanol, dan air. Aktivitas antioksidan dari ekstrak dan fraksi ranting kayu manis dilakukan berbagai pengujian antioksidan seperti kandungan total fenolik, DPPH, NBT, daya reduksi, dan peroksidasi lipid menggunakan homogenat otak tikus. Hasil penelitian menunjukkan bahwa fraksi butanol memiliki kandungan total fenolik tertinggi 496,7 mg ekuivalen asam galat/g dan ditunjukkan kinerja terbaik dalam berbagai pengujian antioksidan. Oleh karena itu, melalui penelitian ini digunakan fraksinasi pelarut n-heksan, etil asetat, butanol, dan air yang diperoleh dari ekstrak metanol daun kayu manis. Metanol digunakan sebagai pelarut dalam proses ekstraksi maserasi karena bersifat lebih polar dan dapat melarutkan hampir semua senyawa metabolit sekunder (Firdausi et al., 2015).

Tanaman kayu manis mengandung senyawa antioksidan yang baik bagi tubuh. Namun sampai saat ini, belum diketahui aktivitas penstabil oksigen singlet dari hasil fraksinasi pelarut n-heksan, etil asetat, butanol dan air dari ekstrak metanol daun kayu manis. Oleh karena itu, dilakukan penelitian untuk menentukan aktivitas penstabil oksigen singlet dari hasil fraksinasi ekstrak metanol daun kayu manis terhadap fotooksidasi asam askorbat. Asam askorbat memiliki sensitivitas yang tinggi dan mudah teroksidasi oleh panas, cahaya, dan udara (Riberio et al., 2011).

\section{Material dan Metode \\ Alat dan Bahan}

Alat yang digunakan yaitu peralatan gelas (Iwaki Pyrex), vortex mixer, oven (Memmert), corong pisah (Iwaki Pyrex), timbangan neraca analitik (Adam PW 254), botol serum berkapasitas $30 \mathrm{~mL}$, rotary evaporator, lampu fluorescent 65 watt, kotak cahaya $70 \times 50 \times 60 \mathrm{~cm}$, spektrofotometer UV-Vis (Shimadzu UV-1800).

Bahan yang digunakan adalah daun kayu manis, pelarut metanol $95 \%$, n-heksan p.a, etil asetat p.a, butanol p.a, larutan $\mathrm{Na}_{2} \mathrm{CO}_{3} 2 \%$, reagen Folin-Ciocelteu $50 \%$, eritrosin, asam galat, aquabidest, dan asam askorbat

\section{Preparasi Sampel}

Sampel daun kayu manis yang diperoleh terlebih dahulu dibersihkan dan dikeringanginkan pada suhu ruang $\left(25^{\circ} \mathrm{C}\right)$ selama 28 hari, selanjutnya dipotong kecil-kecil berukuran $2 \mathrm{~mm}$ lalu diblender dan disaring dengan ayakan 65 mesh sehingga diperoleh serbuk daun kayu manis.

\section{Ekstraksi dan Fraksinasi}

Sebanyak $250 \mathrm{~g}$ serbuk daun kayu manis diekstraksi dengan maserasi menggunakan 1250 $\mathrm{mL}$ metanol $95 \%$ selama 3 x 24 jam. Selanjutnya disaring menggunakan kertas saring dan diperoleh filtrat serta endapan. Filtrat dipekatkan menggunakan rotary evaporator sehingga diperoleh ekstrak kental metanol sebagai ekstrak awal.

Sebanyak $10 \mathrm{~g}$ ekstrak kental metanol dilarutkan dalam $100 \mathrm{~mL}$ aquabidest. Selanjutnya larutan difraksinasi dengan menambahkan $100 \mathrm{~mL}$ 
n-heksan, dikocok dalam corong pisah dan didiamkan selama 10-15 menit hingga terdapat dua lapisan. Diambil lapisan n-heksan, lapisan air dilakukan beberapa kali dengan volume n-heksan yang sama sampai lapisan n-heksan menjadi bening. Lapisan air difraksinasi kembali dengan cara yang sama menggunakan pelarut etil asetat, butanol dan air. Hasil fraksinasi dari n-heksan, etil asetat, butanol dan air diuapkan pelarutnya menggunakan rotary evaporator sehingga diperoleh fraksi n-heksan, etil asetat, butanol dan air

\section{Kandungan Total Fenolik}

Pengujian kandungan total fenolik sampel mengikuti metode Jeong et al. (2004). Sebanyak 0,1 $\mathrm{mL}$ dari masing-masing larutan fraksi $500 \mu \mathrm{g} / \mathrm{mL}$ dimasukkan ke dalam tabung reaksi, ditambahkan dengan 0,1 mL reagen Folin-Ciocalteu (50\%) dalam tabung reaksi dan campuran divortex selama 3 menit. Setelah interval waktu 3 menit, ditambahkan $2 \mathrm{~mL}$ larutan $\mathrm{Na}_{2} \mathrm{CO}_{3} 2 \%$. Selanjutnya campuran diinkubasi dalam ruang gelap selama 30 menit. Dibaca absorbansinya pada $\lambda 750 \mathrm{~nm}$ dengan menggunakan spektrofotometer UV-Vis. Hasil yang diperoleh, diplotkan terhadap kurva standar asam galat yang dipersiapkan dengan cara yang sama. Kandungan total fenolik dihitung sebagai mg ekuivalen asam galat/g fraksi dengan metode Abdelhady et al. (2011) menggunakan persamaan rumus yaitu :

$$
T=C \times \frac{V}{m}
$$

Keterangan :

$\mathrm{T}$ :Kandungan total fenolik (mg/g) dari fraksi sebagai ekuivalen asam galat

C :Konsentrasi asam galat yang terbentuk dari kurva kalibrasi ( $\mathrm{mg} / \mathrm{mL})$

$\mathrm{V}$ :Volume larutan fraksi $(\mathrm{mL})$

$\mathrm{m}$ :Berat fraksi (g)

\section{Aktivitas Penstabil Oksigen Singlet terhadap Fotooksidasi Asam Askorbat}

Penentuan kemampuan penstabil oksigen singlet (SOQ) dalam sampel daun kayu manis terhadap asam askorbat menggunakan metode Jung et al. (1995) yang dimodifikasi. Pengaruh fraksi terhadap fotooksidasi asam askorbat menggunakan konsentrasi 0,6 $\mu \mathrm{g} / \mathrm{mL}$. Masing-masing fraksi 0,6 $\mu \mathrm{g} / \mathrm{mL}$ ditambahkan ke dalam metanol $95 \%$ yang mengandung eritrosin $6 \mu \mathrm{g} / \mathrm{mL}$ dan 100 $\mu \mathrm{g} / \mathrm{mL}$ asam askorbat. Sampel diambil sebanyak 8 $\mathrm{mL}$ dan dimasukkan ke dalam botol serum berukuran $30 \mathrm{~mL}$ serta botol ditutup dengan dilengkapi dengan penutup karet dan aluminium foil. Sampel diletakkan dalam kotak cahaya dengan intensitas cahaya fluoresen 4.000 lux selama 40 menit dengan pengamatan setiap interval waktu 10 menit. selanjutnya sampel di baca absorbansinya pada panjang gelombang $265 \mathrm{~nm}$ dengan menggunakan spektrofotometer UV-Vis. Kuantifikasi konsentrasi asam askorbat dilakukan dengan membuat kurva standar asam askorbat. Sebagai blanko digunakan larutan eritrosin $6 \mu \mathrm{g} / \mathrm{mL}$ dalam metanol $95 \%$. Laju penurunan asam askorbat ditentukan dengan membuat kurva antara konsentrasi asam askorbat (sumbu y) dengan waktu (sumbu x). Slope merupakan laju kerusakan fotooksidatif asam askorbat.

\section{Hasil dan Pembahasan \\ Ekstraksi dan Fraksinasi}

Dari proses ekstraksi maserasi serbuk daun kayu manis, diperoleh ekstrak 48,305 gram dengan warna hijau kehitaman, sehingga diperoleh rendemen sebesar 19,322 \%. Banyaknya ekstrak metanol daun kayu manis yang diperoleh kemungkinan besar mengandung minyak atsiri. Ekstraksi secara maserasi merupakan teknik ekstraksi sederhana karena dilakukan dengan cara merendam sampel dalam pelarut metanol $95 \%$ selama waktu tertentu pada suhu ruang. Pelarut akan menembus dinding sel dan masuk ke dalam rongga sel yang mengandung zat aktif. Zat aktif yang terkandung di dalam sel akan terekstrak keluar karena adanya perbedaan konsentrasi zat aktif di dalam dan di luar sel. Peristiwa tersebut akan terus berlangsung sampai terjadi kesetimbangan konsentrasi antara larutan di dalam dan di luar sel (Chasani et al., 2013).

Dalam proses fraksinasi ekstrak metanol daun kayu manis dilakukan dengan menggunakan pelarut berdasarkan tingkat kepolarannya yaitu n-heksan, etil asetat, butanol, dan air. Hal ini bertujuan agar senyawa metabolit sekunder yang terekstraksi dalam metanol $95 \%$ dapat dikelompokkan menjadi lebih spesifik sesuai kepolaran masing-masing. Hasil fraksinasi yang diperoleh dari setiap pelarut dapat dilihat pada Tabel 1.

Tabel 1. Rendemen Hasil Fraksinasi Ekstrak Metanol Daun Kayu Manis

\begin{tabular}{cccc}
\hline Fraksi & Massa (g) & Rendemen (\%) & Warna \\
\hline FH & 1,507 & 15,055 & Hijau Pekat \\
FEA & 1,303 & 13,017 & Hijau \\
FB & 2,396 & 23,936 & Orange Tua \\
FA & 1,656 & 16,543 & Orange \\
\hline
\end{tabular}

Berdasarkan Tabel 1 terlihat bahwa fraksi butanol (FB) mempunyai rendemen tertinggi diikuti dengan fraksi n-heksan ( $F H)$, fraksi air (FA), dan fraksi etil asetat (FEA). Tingginya rendemen yang terdapat pada pelarut butanol menunjukkan bahwa pelarut tersebut mengandung senyawa metabolit sekunder bersifat semipolar atau polar protik yang mampu mengekstrak lebih banyak komponen bioaktif dari sampel daun kayu manis. Hasil Penelitian sejalan dengan Chua et al. (2008) yang menyatakan bahwa rendemen yang tinggi ditunjukkan pada fraksi butanol dan mengandung senyawa isolat murni yaitu kaempferol-7-0rhamnoside. Menurut Soeksmanto et al. (2007) menyatakan bahwa penggunaan pelarut yang 
berbeda tingkat kepolaran mempengaruhi jenis senyawa yang terekstrak.

\section{Kandungan Total Fenolik}

Penentuan kandungan total fenolik masingmasing fraksi dinyatakan sebagai ekuivalen asam galat. Ekuivalen asam galat merupakan acuan umum untuk mengukur sejumlah senyawa fenolik yang terdapat dalam suatu bahan (Mongkolsilp et al., 2004).

Analisis kandungan total fenolik dilakukan dengan membuat kurva standar asam galat dari konsentrasi dengan absorbansi sehingga diperoleh persamaan regresi yaitu y $=0,0063 x+0,0578$ dengan $R^{2}=0,9967$. Nilai $R^{2}$ atau koefisien determinasi merupakan angka yang nilainya berkisar 0 sampai 1 yang menunjukkan seberapa dekat nilai perkiraan untuk analisis regresi yang mewakili data yang sebenarnya. Analisis regresi dapat dipercaya jika nilai $\mathrm{R}^{2}$-nya sama dengan atau mendekati 1.

Penggunaan asam galat sebagai larutan standar dikarenakan senyawa asam galat mempunyai gugus hidroksil dan ikatan rangkap yang terkonjugasi pada masing-masing cincin benzena yang menyebabkan senyawa ini sangat efektif untuk membentuk senyawa kompleks dengan reagen folin-ciocalteu, sehingga reaksi yang terjadi lebih sensitif dan intensif (Julkunen-Tiito, 1985). Menurut Agbor et al. (2014) reaksi kimia yang terjadi dengan reagen folin ciocalteu sebagai berikut.

$$
\begin{gathered}
\mathrm{Na}_{2} \mathrm{WO}_{4} / \mathrm{Na}_{2} \mathrm{MoO}_{4(\text { Kuning })} \longrightarrow\left(\text { Fenol- } \mathrm{MoW}_{11} \mathrm{O}_{40}\right)^{-4}{ }_{(\text {Biru })} \\
\mathrm{Mo}^{6+}{ }_{\text {(Kuning) }}+\mathrm{e}^{-} \longrightarrow \mathrm{Mo}^{5+}{ }_{(\text {Biru })}
\end{gathered}
$$

Kandungan total fenolik ditentukan berdasarkan kemampuan senyawa fenolik dalam daun kayu manis yang bereaksi dengan asam fosfomolibdat-fosfotungstat dari reagen folinciocalteu (berwarna kuning) yang menghasilkan senyawa kompleks yaitu molibdenum-tungstat berwarna biru (Julkunen-Tiito, 1985). Warna kuning pada reagen folin-ciocalteu akan mengalami perubahan warna menjadi warna biru karena adanya reaksi dengan fraksi. Reaksi tersebut tidak terjadi jika dalam suasana asam, oleh karena itu, pada pengujian ini digunakan larutan $\mathrm{Na}_{2} \mathrm{CO}_{3} 2 \%$ yang besifat basa sehingga menyebabkan terjadinya reaksi reduksi folin-ciocalteu oleh gugus hidroksil dari senyawa fenolik dalam sampel (Nely, 2007)

Dari hasil fraksinasi ekstrak metanol daun kayu manis diperoleh fraksi n-heksan, fraksi etil asetat, fraksi butanol dan fraksi air yang diuji kandungan total fenolik dengan konsentrasi $500 \mu \mathrm{g} / \mathrm{mL}$ dapat di lihat pada Gambar 1.

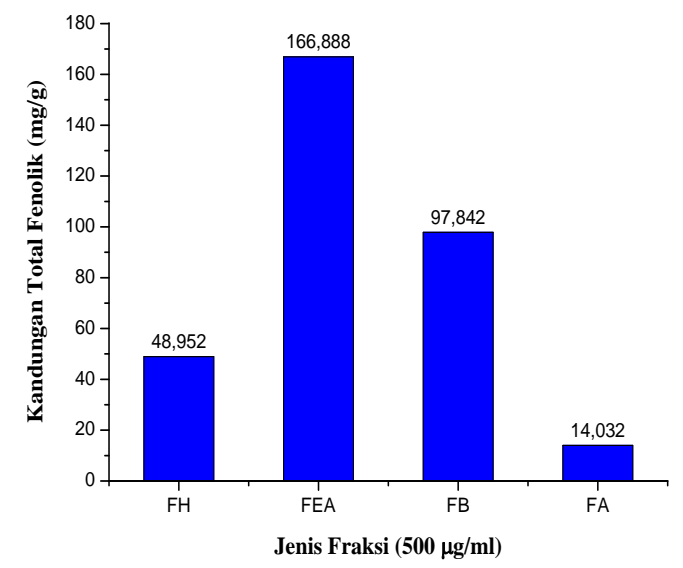

Gambar 1. Kandungan total fenolik hasil fraksinasi ekstrak metanol daun kayu manis

Berdasarkan Gambar 1 dapat diketahui bahwa kandungan total fenolik tertinggi yaitu fraksi etil asetat (FEA) sebesar 166,888 mg/g diikuti dengan fraksi butanol (FB) $97,842 \mathrm{mg} / \mathrm{g}$, fraksi n-heksan (FH) 48,952 mg/g dan fraksi air (FA) 14,032 mg/g. $\mathrm{Hal}$ ini dikarenakan pelarut etil asetat dapat melarutkan senyawa fenolik yang lebih banyak sehingga menunjukkan sebagian besar senyawa fenolik yang terdapat pada daun kayu manis merupakan senyawa yang bersifat semipolar atau polar aprotik.

Semakin besar kandungan total fenolik dari sampel daun kayu manis, semakin banyak ion fenolat yang terbentuk sehingga warna biru yang dihasilkan semakin pekat. Singleton dan rossi (1965) mengatakan bahwa warna biru yang teramati berbanding lurus dengan konsentrasi ion fenolat yang terbentuk, sehingga warna biru yang dihasilkan semakin pekat. Menurut khadambi (2007) semakin banyak jumlah gugus hidroksil fenolik, semakin besar konsentrasi komponen fenolik yang terdeteksi.

\section{Aktivitas Penstabil Oksigen Singlet terhadap Fotooksidasi Asam Askorbat}

Pengujian aktivitas penstabil oksigen singlet terhadap fotooksidasi asam askorbat ditentukan berdasarkan laju penurunan konsentrasi asam asrkorbat dari sampel tersebut, dalam hal ini berhubungan langsung dengan kinetika reaksi kimia, bila mana perubahan konsentrasi dipengaruhi oleh waktu. Analisis kuantifikasi konsentrasi asam askorbat dilakukan dengan membuat kurva standar asam askorbat dari konsentrasi dengan absorbansi sehingga diperoleh persamaan regresi yaitu $y=0,0003 x+0,6619$ dengan $\mathrm{R}^{2}=0,9917$.

Aktivitas penstabil oksigen singet dari hasil fraksinasi ekstrak metanol daun kayu manis dilakukan setelah proses fotooksidasi asam askorbat menggunakan eritrosin sebagai sensitiser 
yang uji dengan konsentrasi $0,6 \mu \mathrm{g} / \mathrm{mL}$ dapat dilihat pada Gambar 2.

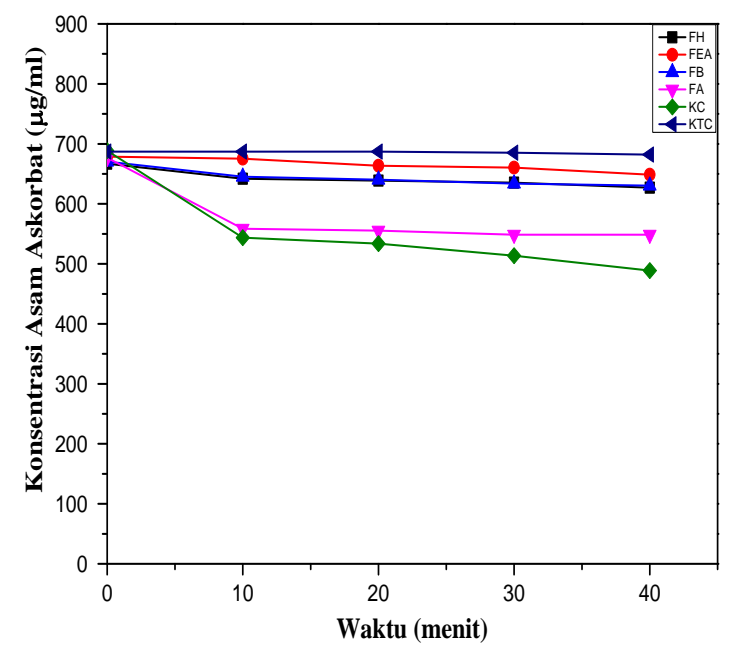

Gambar 2. Efek $0,6 \mu \mathrm{g} / \mathrm{mL}$ masing-masing fraksi terhadap fotooksidasi asam askorbat yang diinduksi oleh eritrosin selama 40 menit

Penstabilan oksigen singlet terjadi secara kimiawi di mana pada proses fotooksidasi asam askorbat terbentuk produk oksidasi yaitu senyawa hidroperoksida. Senyawa hidroperoksida dari asam askorbat tersebut diukur absorbansinya pada panjang gelombang $265 \mathrm{~nm}$ dengan menggunakan spektrofotometer UV-Vis. Selanjutnya diinterpolasikan ke dalam persamaan regresi yang didapat sehingga diperoleh konsentrasi asam askorbat dari sampel fraksi untuk setiap interval waktu yang diamati secara berurutan dari 10 sampai 40 menit. konsentrasi asam askorbat dari masing-masing fraksi daun kayu manis, dinyatakan sebagai mikrogram per mililiter per menit $\left(\mu \mathrm{g} . \mathrm{mL}^{-}\right.$ 1. menit $\left.^{-1}\right)$.

Berdasarkan Gambar 2 dapat diketahui bahwa aktivitas penstabil oksigen singlet yang besar menunjukkan konsentrasi asam askorbat dari sampel uji mengalami penurunan yang cukup kecil, dilihat dari laju penurunan konsentatsi asam askorbat diatas kontrol dengan cahaya (KC) dan mendekati kontrol tanpa cahaya (KTC). Oleh karena itu, dari setiap fraksi yang menunjukkan laju penurunan konsentrasi asam askorbat cukup kecil adalah fraksi etil asetat (FEA), hal ini berpengaruh pada kandungan total fenolik yang tinggi sehingga menunjukkan potensi sebagai penstabil oksigen singlet sangat besar.

Dari Gambar 2 dapat dilihat bahwa semakin lama waktu penyinaran, semakin menurunnya konsentrasi asam askorbat yang ditunjukkan dengan laju kerusakan fotooksidatif asam askorbat dalam sampel uji. Hal ini disebabkan adanya eritrosin sebagai sensitiser yang dapat menyerap energi cahaya dan mentransfer kelebihan energinya ke oksigen triplet membentuk oksigen singlet. Oksigen singlet inilah yang mengoksidasi asam askorbat sehingga mengakibatkan konsentrasinya berkurang. Laju kerusakan fotooksidatif asam askorbat dari setiap fraksi pada daun kayu manis dapat ditentukan dengan cara diplotkan konsentrasi dengan waktu penyinaran 10, 20, 30, dan 40 menit sehingga diperoleh nilai slope atau koefisien regresi yang menunjukkan bahwa laju kerusakan fotooksidatif asam askorbat pada sampel tersebut. Laju kerusakaan fotooksidatif asam askorbat dapat dilihat pada Tabel 2.

Tabel 2. Pengaruh $0,6 \mu \mathrm{g} / \mathrm{mL}$ dari masing-masing fraksi dalam menghambat kerusakan fotooksidatif asam askorbat

\begin{tabular}{cc}
\hline Fraksi & $\begin{array}{c}\text { Laju Kerusakan Fotooksidatif } \\
\text { Asam Askorbat }\left(\mu \mathrm{g} \cdot \mathrm{mL}^{-1} \cdot \text { menit }^{-1}\right)\end{array}$ \\
\hline FH & $-1,0667$ \\
FEA & $-0,75$ \\
FB & $-0,9167$ \\
FA & $-2,6667$ \\
KC & $-4,3$ \\
KTC & $-0,1167$ \\
\hline
\end{tabular}

Berdasarkan Tabel 2 dapat diketahui bahwa masing-masing fraksi dari kayu manis memiliki potensi sebagai penstabil oksigen singlet. Semakin besar penstabil oksigen singlet, semakin kecil laju kerusakan akibat fotooksidatif asam askorbat pada setiap fraksi daun kayu manis. Laju kerusakan fotooksidatif asam askorbat dari masing-masing fraksi dimulai dari yang terkecil hingga besar adalah fraksi etil asetat (FEA), fraksi butanol (FB), fraksi n-heksan (FH), dan fraksi air (FA) dengan nilai berturut-turut yaitu $-0,75 ;-0,9167 ;-1,0667$; dan $-2,6667 \quad\left(\mu \mathrm{g} \cdot \mathrm{mL}^{-1} \cdot \mathrm{menit}^{-1}\right)$. Hal ini mungkin disebabkan bahwa senyawa-senyawa yang aktif dari fraksi etil asetat pada daun kayu manis, bertindak sebagai quencer atau penstabil oksigen singlet sehingga dalam menghambat proses fotooksidasi asam askorbat sangat besar sampai menit ke 40 . Jenis senyawa yang terekstrak dalam daun kayu manis dari pelarut yang berbeda akan menghasilkan besar kecilnya kemampuan dalam menghambat terjadinya fotooksidasi asam askorbat. Oleh karena itu, pada fraksi air (FA) daun kayu manis yang mengandung senyawa polar memiliki laju kerusakan fotooksidatif asam askorbat sangat besar. Van bree et al. (2012) menyatakan bahwa laju kerusakan vitamin C (asam askorbat) dipengaruhi oleh kelarutan oksigen dalam pelarut. Asam askorbat merupakan antioksidan alami yang bertindak sebagai quencer oksigen singet sehingga dijadikan subyek untuk pengujian fotooksidasi.

\section{Kesimpulan \\ Kandungan total fenolik tertinggi dari hasil} fraksinasi ekstrak metanol daun kayu manis ditunjukkan oleh fraksi etil asetat diikuti dengan fraksi butanol, n-heksan, dan air. Fraksi etil asetat memiliki laju kerusakan fotooksidatif asam askorbat sangat kecil sehingga berpotensi sebagai penstabil oksigen singlet. Semakin kecil laju kerusakan fotooksidatif asam 
askorbat, semakin besar aktivitas penstabil oksigen singlet

\section{Daftar Pustaka}

Abdelhady, M.I.S., Motaal, A.A., dan Beerhues, L. 2011. Total Phenolic Content and Antioxidant Activity of Standardized Extracts from Leaves and Cell Cultures of Three Callistemon Species. American Journal of Plant Sciences. 2: 847-850

Agbor, G.A., Vinson, J.A. dan Donnelly, P.E. 2014. Folin-Ciocalteau Reagent for Polyphenolic Assay. International Journal of Food Science, Nutrition and Dietetics. 3: 147-156

Araujo, V., Arnal, C. Boronat, M., Ruiz, E. dan Dominguez, C.1998. Oxidant-antioxidant Imbalance in Blood of Children with Juvenile Rheumatoid Arthritis. Biofactors. 8: 155-159

Chasani, M., Fitriaji, R. B. dan Purwati. 2013. Fraksinasi Ekstrak Metanol Kulit Batang Ketapang (Terminalia catappa Linn.) dan Uji Toksisitasnya dengan Metode BSLT (Brine Shrimp Lethality Test). Molekul. 1: 89-100

Choe, E. dan Min D.B. 2006. Chemistry and Reaction of Reactive Oxygen Species in Foods. Critical Reviews in Food Science and Nutrition. 46: 1-22

Chua, M.T., Tung, Y.T. dan Chang, S.T. 2008. Antioxidant Activities of Ethanolic Extracts from The Twigs of (Cinnamomum osmophloeum). Bioresource Technology. 99: 1918-1925

Firdausi, I., Retnowati, R. dan Sutrisno. 2015. Fraksinasi Ekstrak Metanol Daun Mangga Kasturi (Mangifera casturi Kosterm) dengan Pelarut n-Butanol. Kimia.Student Journal. 1: 785-790

Heyne, K. 1987. Tanaman Berguna di Indonesia Jilid I, II, dan III. Terjemahan Litbang Kehutanan. Departemen Kehutanan dan Yayasan Sarana Wanajaya, Jakarta

Jakhetia, V., Patel, R., Khatri, P., Pahuja, N., Garg, S., Pandey, A., dan Sharma, S. 2010. Cinnamon a Pharmacological Review. Journal of Advanced Scientific Research. 1: 19-23.

Jeong, S.M., Kim, S.Y., Kim, D.R., Jo, S.C., Nam, K.C., Ahn, D.U. dan Lee, S.C. 2004. Effect of Heat Treatment on the Antioxidant Activity of Extracts from Citrus Peels. Journal of Agricultural and Food Chemistry. 52: 33893393.

Singleton, V.L. dan Rossi, J.A.Jr. 1965. Colorimetry of Total Phenolics with PhosphomolybdicPhosphotungstic Acid Reagents. American Journal Enology and Viticulture. 16: 145-147.

Julkunen-Tiitto, R. 1985. Phenolic Constituents in the Leaves of Northern Willows: Methods for the Analysis of Certain Phenolics. Journal of Agricultural and Food Chemistry. 33: 213-217.

Khadambi. 2007. Extraction of Phenolic Compounds and Quantification of The Total Phenol

and Condensed Tannin Content

of Bran Fraction of Condensed Tannin and Condensed Tannin Free Sorghum Varieties.http://upetd.up.ac.za/thesis/available /etd-03022007-64705/unrestricted/02 Chapter2 pdf. [26 April 2007].

King, J.M. dan D.B. Min. 2002. RiboflavinPhotosensitized Singlet Oxygen Oxidation Product of Vitamin D2. Journal of the American Oil Chemists'Society. 79: 983-987.

Meucci, E., Mordente, A. dan Martorana, G.E. 1991. Metal-catalyzed Oxidation of Human Serum Albumin; Conformational and Functional Changes. Implications in protein aging. Journal of Biological Chemistry. 266: 4692-4699.

Min, D.B. dan Boff. J.M. 2002. Chemistry and Reaction of Singlet Oxygen in Foods. Comprehensive Reviews in Food Science and Food Safety. 1: 58-72.

Mongkolsilp, S., Pongbupakit, I., Sae-lee, N. dan Sitthithaworn, W. 2004. Radical Scavenging activity and total phenolic content of medical plants used in primary health care. Jurnal of Pharmacy and Science. 9: 32-35.

Nely, F. 2007. Aktivitas Antioksidan Rempah Pasar dan Bubuk Rempah Pabrik dengan Metode Polifenol dan Uji Aom (Active Oxygen Method). [Skripsi]. Fakultas Teknologi Pertanian IPB, Bogor

Pokorny, J., Yanishlieva, N. dan Gordon, M. 2001. Antioxidants in Food. CRC Press. Boca Raton Boston New York, Washington, DC.

Riberio, D.O., Pinto, D.C., Lima, L.M.T.R.,Volpato, N.M., Cabral, L.M. dan Sousa, V.P. 2011. Chemical Stability Study of Vitamin Thiamine, Riboflavin, Pyridoxine and Ascorbic Acid in Parental Nutrition for Neonatal Use. Nutrition Journal. 10: 47-57.

Silva, F.A.M., Borges, F., Guimarães, C., Lima, J.L.F.C., Matos, C. dan Reis, S. 2000. Phenolics Acid and Derivatives: Studies on the Relationship Among Structure, Radical Scavenging Activity and Physiochemical Parameters. Journal of Agricultural and Food Chemistry. 48: 21222126.

Sufriadi, A. 2006. Manfaat Daun Kayu manis (Cinnamomum burmanni) terhadap khasiat antioksidasi mahkota dewa (Phaleria macrocarpa (scheff.) Boerl.) Selama penyimpanan. [Skripsi]. FMIPA IPB, Bogor

Van Bree, I., Baetens, J.M., Samapundo, S., Devlieghere, F., Laleman, R.,Vandenkinderen, I., Noseda, B., Xhaveri, R., De Baets, B. dan De Meulenaer, B. 2012. Modelling The Degradation Kinetics of Vitamin C in Fruit Juice in Relation to The Initial Headspace Oxygen Concentration. Food Chemistry. 134: 207-2014 . 